\title{
A comparison of the digestion and reduction in particle size of lucerne hay (Medicago sativa) and Italian ryegrass hay (Lolium italicum) in the ovine digestive tract
}

\author{
BY E. GRENET \\ Station de Recherches sur la Nutrition des Herbivores, Unité de l'Ingestion, INRA, Centre de \\ Recherches de Clermont-Ferrand/Theix, 63122 Ceyrat, France
}

(Received 13 May 1988-Accepted 20 March 1989)

\begin{abstract}
Four types of hay were used: an early-cut and a late-cut lucerne (Medicago sativa) and an early-cut and a late-cut ryegrass (Lolium italicum). Digestibility and voluntary intake were measured on six adult sheep maintained in metabolism crates and fed $10 \%$ above the previous day's consumption, in equal portions at 08.00 and 16.30 hours. Lucerne intake was higher than that of ryegrass at similar digestibilities. The rate of digestion of the four hays was measured using nylon bags and the rates of digestion of dry matter for late-cut lucerne were faster than those for the late-cut ryegrass. Eleven adult sheep fitted with oesophageal (four), rumen (four) or duodenal (three) fistulas were used for collecting digesta samples at the different sites. They were fed successively with the four hay types. Each was offered to appetite, once daily, in a meal taken over $4 \mathrm{~h}$. The rumen of rumen-fistulated sheep was completely emptied by hand once before feeding ( 08.00 hours) and once after removal of refusals (12.00 hours). The number of times the ingested hay was chewed during the meal and the time spent masticating was greater for the late-cut hays and greater for the ryegrass compared with the lucerne hays. The particle size of the boluses was greater than that of the rumen contents, which in turn was greater than that of the duodenal contents and faeces. The percentage of particles $>8 \mathrm{~mm}$ in the boluses from the ryegrass was higher than that of lucerne, and that of the early-cut ryegrass was greater than that of the late-cut ryegrass. This was also the case for the percentage of particles $>1.6 \mathrm{~mm}$ in the rumen contents after the meal. The rate at which dry matter disappeared from the rumen was greatest during the meal except with late-cut ryegrass; it was particularly high with late-cut lucerne, a little less with early-cut ryegrass and much lower with the other two hays. When nylon bags containing food boluses were placed in the rumen, it was apparent that without rumination, with the exception of the very digestible earlycut ryegrass, microbial degradation alone did not reduce the particle size.
\end{abstract}

Digestion: Rumen emptying: Sheep

It is generally held that feedstuffs can only leave the rumen after reduction of the particulate matter to less than a critical size: $1 \mathrm{~mm}$ in sheep (Poppi et al. 1980), and $2 \mathrm{~mm}$ in cattle (Grenet, 1970; Ulyatt et al. 1986). The reduction in particle size results from microbial digestion and mastication. Although ingestive mastication is important, the essential role in particle breakdown is played by rumination (Ulyatt et al. 1986): microbial digestion renders the plant material more sensitive to rumination.

The ease with which plant material can be broken down into small particles depends on the histological structure of the forage plants. It is known that the histological structure of legumes differs from that of grasses (Grenet \& Demarquilly, 1987). The presence of supportive tissues, lignified in ryegrass and non-lignified in lucerne, the volume of xylem tissues (always lignified) and their arrangement in the plant in the form of a closed ring in lucerne or scattered in the parenchyma of ryegrass, are all factors which affect the resistance of plants to physical breakdown. 
Voluntary intake of legumes is higher than that of grasses at similar digestibilities. The objective of the present experiment was to study the mechanisms which give rise to this difference. For this a comparison was made of the feeding behaviour of sheep fed on lucerne or ryegrass. The experiments assess the time spent masticating, measure the degree of rumen fill and calculate its emptying rate. The relative influence of mastication and of the microbial degradation on the comminution of feeds was estimated.

\section{MATERIALS AND METHODS}

Foodstuffs. Four types of hay were used: an early-cut lucerne hay (Medicago sativa cv Europe) harvested on 25 July after a $20 \mathrm{~d}$ regrowth, a late-cut lucerne hay harvested at full bloom on 8 June in the primary growth stage, a very-early-cut Italian-ryegrass hay (Lolium italicum $\mathrm{cv}$ Tiara) harvested at early stem elongation on 1 May in the primary growth stage, and a late-cut Italian-ryegrass hay harvested on 8 June at full bloom.

Animal feeding. Six adult Texel wethers with a mean weight of $60 \mathrm{~kg}$, maintained in metabolism crates, were fed successively on the early-cut lucerne, the late-cut ryegrass, the early-cut ryegrass and the late-cut lucerne as chopped hays. Digestibility and voluntary intake were measured according to the method described by Demarquilly \& Weiss (1970). A pre-experimental period of $15 \mathrm{~d}$ was followed by an experimental period of $6 \mathrm{~d}$. The sheep were fed at $10 \%$ above the previous day's consumption, in equal portions at 08.00 and 16.30 hours, and the uneaten feed was removed before the morning allocation.

The other animals used in the study were adult Texel wethers, fitted with either oesophageal (four), rumen (four) or duodenal (three) fistulas (and cannulas) and weighing $60-90,80-90$ and $45-58 \mathrm{~kg}$ respectively. They were fed successively, in the same order as described earlier, with the four hay types ad lib. (10\% refusal) in a single meal at 08.00 hours and refusals were removed daily at 12.00 hours. A pre-experimental period of $15 \mathrm{~d}$ was followed by an experimental period of $30 \mathrm{~d}$.

Particle size analysis at different sites of the digestive tract; measurement of the rumen contents and the digesta leaving the rumen. The following samples were collected: (1) bolus material in the morning at the moment of feeding on $1 \mathrm{~d}$ in the four oesophageal-fistulated sheep by removing the cannula for $0 \cdot 5-1 \mathrm{~h}$ and by letting the boluses fall into a bag fixed at the neck of the animal; (2) boluses, collected by hand, at the moment of rumination on $1 \mathrm{~d}$ from a varying number of sheep (one for early-cut lucerne, two for late-cut lucerne and ryegrass, three for early-cut ryegrass), between 14.00 and 15.30 hours, by separating the regurgitated boluses before mastication from those which were reswallowed after mastication. A mean sample of boluses collected during feed ingestion in the four sheep was retained for analysis while the boluses obtained at the moment of rumination were stored and analysed separately for each sheep.

To sample rumen contents in the rumen-fistulated animals, the rumen of all animals was completely emptied by hand once before feeding ( 08.00 hours) and once after removal of refusals (12.00 hours). This was done at intervals no shorter than $2 \mathrm{~d}$ and no longer than $7 \mathrm{~d}$ to avoid the possibility of an effect of the first rumen-emptying on the second rumenemptying (Aitchison, 1985). A representative sample of rumen contents weighing approximately $700 \mathrm{~g}$ was collected and homogenized.

Duodenal contents were collected from the fistulated animals just before the meal and 4 $\mathrm{h}$ later by allowing them to flow freely into a $200 \mathrm{ml}$ bottle fixed at the outlet of the cannula. These samples were collected for five consecutive days (days 16-20).

A mean sample of the faeces voided during the experimental period (from $4 \mathrm{~d}$ ) was collected from the rumen- and duodenally-fistulated animals maintained in metabolism crates. 
Samples of digestive contents and faeces were stored at $-15^{\circ}$ before particle size analysis.

Record of feeding behaviour. Feeding behaviour was recorded by the method of Ruckebusch (1963) (see also Dulphy, 1971), which allows measurements of daily time spent eating and ruminating. These were made in three rumen-fistulated sheep for five consecutive days; the rate of progress of the recording chart was increased for $3 \mathrm{~d}$ in order to count the number of chews for four periods of $5 \mathrm{~min}$ at $1 \mathrm{~h}$ intervals between 08.00 and 12.00 hours. The amounts ingested by the animals during these 5 -min periods were measured by weighing the refusals immediately before and after.

In situ degradation studies. Nylon bags containing $3 \mathrm{~g}$ dry matter (DM) of the four hay types were prepared according to the method of Demarquilly \& Chenost (1969). These bags were placed in the rumen of the fistulated sheep fed on the experimental hay for $1 \cdot 5,4,8$, 24,48 and $72 \mathrm{~h}$. They were washed as soon as they were removed from the rumen and weighed as described by Demarquilly \& Chenost (1969). The fractional rates of digestion were estimated by fitting the values for percentage disappearance of DM with time to the equation:

$$
Y=b_{0}+b_{1} e^{-b_{2} t}+b_{3} e^{-b_{4} t},
$$

where $Y$ is the DM remaining in the bag, $b_{0}$ is undegradable $\mathrm{DM}, b_{1}$ is rapidly degradable $\mathrm{DM}, b_{3}$ is slowly degradable DM, $b_{2}$ and $b_{4}$ are the fractional rates of digestion of $b_{1}$ and $b_{3}$ respectively, and $t$ is the period of incubation.

Nylon bags containing boluses collected fresh during ingestion and corresponding to 3 g DM were prepared according to the method of Demarquilly \& Chenost (1969). These bags were placed in the rumen of the fistulated sheep fed on the experimental hay for 8,24 , 48 and $72 \mathrm{~h}$. When the bags were withdrawn they were washed and stored at $-15^{\circ}$ for particle size analysis.

Analytical methods. Samples of forages offered, refusals and faeces corresponding to each experimental period were analysed to determine their ash, crude fibre and nitrogen contents. Total $\mathrm{N}$ content was determined by the Kjeldahl method, ash as material remaining after ignition at $600^{\circ}$ and crude fibre by the Weende method.

The cell wall and the crude lignin contents of the hay types were determined according to the method of Goering \& Van Soest (1970).

The particle size analysis of the digestive contents was carried out by wet sieving (Grenet, 1984).

Statistical analysis. Means and standard deviations of the means were calculated for each hay type. Individual results were subjected to an analysis of variance using the general linear model procedure; pairwise comparisons were performed based on the Studentized maximum modulus (SAS, 1985).

\section{RESULTS}

Chemical composition and nutritive value of the four hay types. The DM content of the four hay types was approximately $860 \mathrm{~g} / \mathrm{kg}$. Their chemical composition and nutritive value (Table 1) varied; the late hays had a higher cell-wall content and were thus less digestible than the early ones. The two ryegrasses differed much more from each other in their organic matter (OM) digestibility (a difference of 0.2 ) than the two lucerne hays (a difference of 0.07 ). The $O M$ digestibilities of the two late-cut hays were similar, 0.592 and 0.553 for lucerne and ryegrass respectively, while their cell-wall contents differed, lucerne containing less neutral-detergent fibre than ryegrass (536 and $663 \mathrm{~g} / \mathrm{kg}$ DM respectively), but a little more acid-detergent fibre (368 and $339 \mathrm{~g} / \mathrm{kg}$ DM respectively). At similar digestibilities, the voluntary intake of lucerne hay was larger than that of ryegrass (late-cut lucerne $66.1 \mathrm{~g} / \mathrm{kg}$ body-weight $(\mathrm{W})^{0.75} v$. ryegrass $48.5 \mathrm{~g} / \mathrm{kg} \mathrm{W}^{0.75}$ ). 


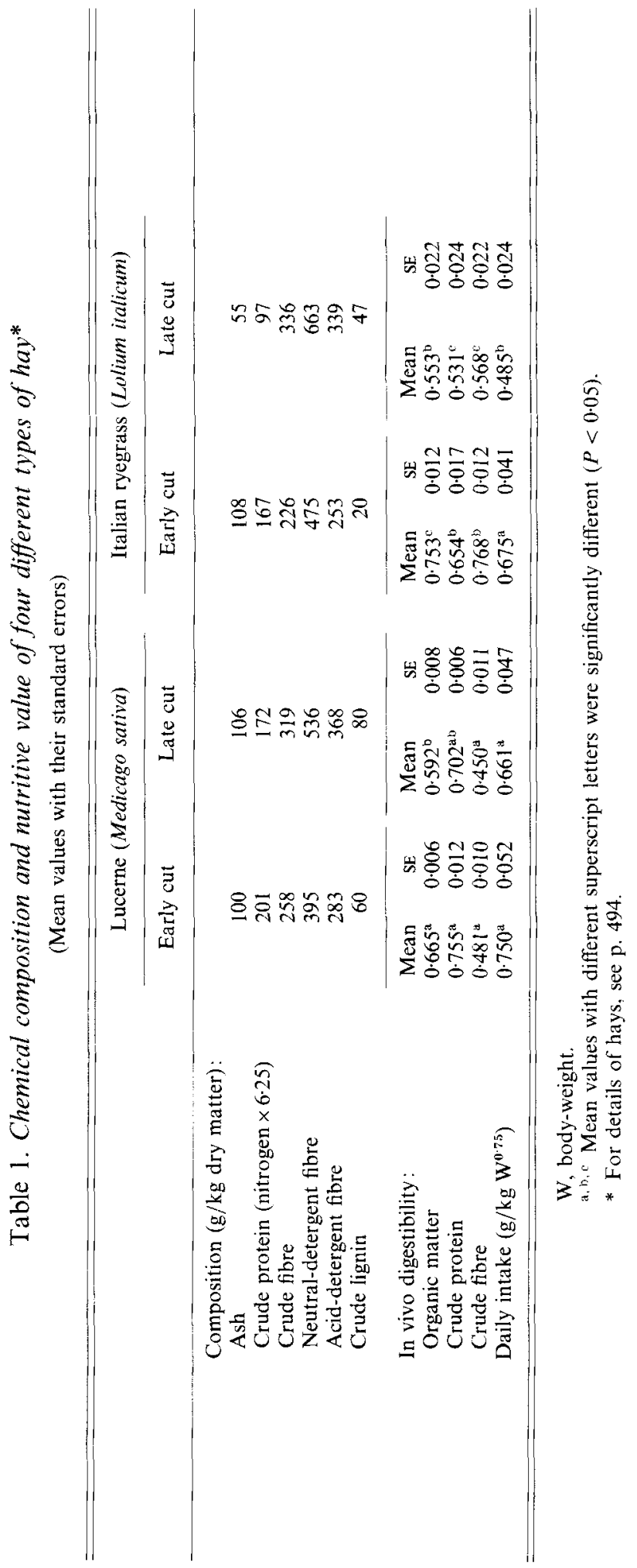


Table 2. Fractional rates of digestion $(/ h)$ of dry matter rapidly degraded $\left(\mathrm{b}_{2}\right)$ and slowly degraded $\left(\mathrm{b}_{4}\right)$ from four types of hay*

(Mean values with their standard errors)

\begin{tabular}{|c|c|c|c|c|c|c|c|c|}
\hline & \multicolumn{4}{|c|}{ Lucerne (Medicago sativa) } & \multicolumn{4}{|c|}{ Italian ryegrass (Lolium italicum) } \\
\hline & \multicolumn{2}{|c|}{ Early cut } & \multicolumn{2}{|c|}{ Late cut } & \multicolumn{2}{|c|}{ Early cut } & \multicolumn{2}{|c|}{ Late cut } \\
\hline & Mean & SE & Mean & SE & Mean & SE & Mean & SE \\
\hline $\begin{array}{l}b_{2} \\
b_{4}\end{array}$ & $\begin{array}{l}2 \cdot 3691^{\mathrm{ab}} \\
0 \cdot 0489^{\mathrm{a}}\end{array}$ & $\begin{array}{l}0.5565 \\
0.0034\end{array}$ & $\begin{array}{l}2 \cdot 5771^{\mathrm{a}} \\
0 \cdot 0457^{\mathrm{ab}}\end{array}$ & $\begin{array}{c}0.3808 \\
0.0038\end{array}$ & $\begin{array}{l}1.8348^{\mathrm{ab}} \\
0.0278^{\mathrm{bc}}\end{array}$ & $\begin{array}{l}0.1531 \\
0.0059\end{array}$ & $\begin{array}{l}0.8185^{b} \\
0.0226^{c}\end{array}$ & $\begin{array}{l}0.1410 \\
0.0028\end{array}$ \\
\hline
\end{tabular}

a.b, e Mean values with different superscript letters were significantly different $(P<0 \cdot 05)$.

* For details of hays, see p. 494 and Table 1.

Table 3. Feeding behaviour of sheep fed on four different types of hay*

(Mean values with their standard errors)

\begin{tabular}{|c|c|c|c|c|c|c|c|c|}
\hline & \multicolumn{4}{|c|}{ Lucerne (Medicago sativa) } & \multicolumn{4}{|c|}{ Italian ryegrass (Lolium italicum) } \\
\hline & \multicolumn{2}{|c|}{ Early cut } & \multicolumn{2}{|c|}{ Late cut } & \multicolumn{2}{|c|}{ Early cut } & \multicolumn{2}{|c|}{ Late cut } \\
\hline & Mean & $\mathrm{SE}$ & Mean & SE & Mean & $\mathbf{S E}$ & Mean & SE \\
\hline \multicolumn{9}{|c|}{ Daily time spent (min) ( $n$ 15) } \\
\hline Eating & $144^{\mathrm{ac}}$ & 11 & $240^{\mathrm{b}}$ & 19 & $107^{\mathrm{a}}$ & 6 & $175^{\mathrm{c}}$ & 9 \\
\hline Ruminating & $336^{a}$ & 28 & $516^{\mathrm{b}}$ & 18 & $344^{\mathrm{a}}$ & 20 & $526^{\mathrm{b}}$ & 16 \\
\hline Chewing & $480^{\mathrm{a}}$ & 38 & $767^{\mathrm{b}}$ & 29 & $451^{a}$ & 20 & $701^{\mathrm{b}}$ & 21 \\
\hline \multicolumn{9}{|c|}{ Unit time (min/kg DM) (n 15) } \\
\hline Eating & $130^{a b}$ & 7 & $147^{\mathrm{a}}$ & 11 & $97^{\mathrm{b}}$ & 3 & $211^{\mathrm{c}}$ & 10 \\
\hline Ruminating & $304^{\mathrm{a}}$ & 18 & $305^{\mathrm{a}}$ & 11 & $322^{\mathrm{a}}$ & 25 & $637^{\mathrm{b}}$ & 18 \\
\hline Chewing & $434^{\mathrm{a}}$ & 20 & $452^{a}$ & 17 & $419^{a}$ & 24 & $848^{b}$ & 24 \\
\hline \multicolumn{9}{|c|}{ Level of DM intake $(\mathrm{g})(n 9)$} \\
\hline lst hour & $647^{a b}$ & 29 & $696^{\mathrm{b}}$ & 44 & $687^{\mathrm{b}}$ & 68 & $408^{a}$ & 38 \\
\hline 2nd hour & $307^{\mathrm{a}}$ & 25 & $480^{b}$ & 15 & $262^{\mathrm{a}}$ & 38 & $287^{a}$ & 12 \\
\hline During $4 \mathrm{~h}$ & $1154^{\mathrm{a}}$ & 50 & $1638^{\mathrm{b}}$ & 43 & $1128^{\mathrm{a}}$ & 77 & $871^{\mathrm{a}}$ & 56 \\
\hline
\end{tabular}

DM, dry matter.

$a, b, c$ Mean values with different superscript letters were significantly different $(P<0 \cdot 05)$.

* For details of hays, see p. 494 and Table 1.

Rates of digestion. The fractional rates of digestion of DM from the nylon bags are shown in Table 2. The rates of digestion of DM were higher for the late-cut lucerne hay than for the late-cut ryegrass hay.

Feeding activities. The results presented in Tables 3 and 4 show that in the fistulated sheep fed once daily on a meal taken over $4 \mathrm{~h}$, the level of intake of early-cut lucerne was lower than that of late-cut lucerne. This was not observed in the intact sheep fed on two meals/d to measure the digestibility and the feed intake (Table 1), but was found consistently in the fistulated sheep receiving a single meal daily both during recording of feeding activities (Table 3) and during rumen emptying (Table 4). This low level of intake markedly influenced all the results obtained with this lucerne.

The feeding activities of sheep receiving a single meal daily of one of the four hay types are described in Table 3. The sheep spent less time per day chewing the early-cut hays than 
E. GRENET

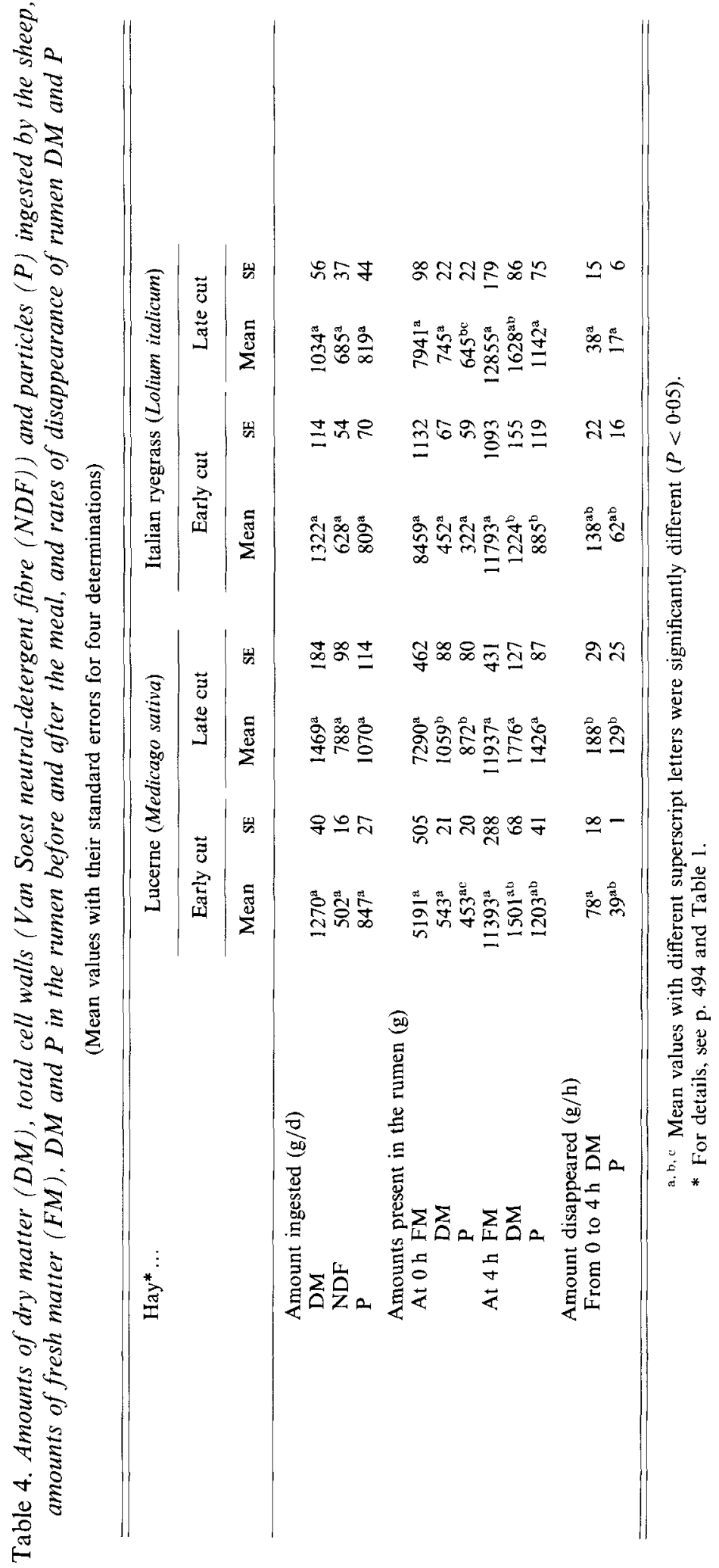


Table 5. Number of chews/min during the meal for sheep fed on four types of hay*

(Mean values with their standard errors for eighteen determinations)

\begin{tabular}{|c|c|c|c|c|c|c|c|c|}
\hline \multirow{3}{*}{$\begin{array}{l}\text { Period after the beginning } \\
\text { of the meal }(h)\end{array}$} & \multicolumn{4}{|c|}{ Lucerne (Medicago sativa) } & \multicolumn{4}{|c|}{ Italian ryegrass (Lolium italicum) } \\
\hline & \multicolumn{2}{|c|}{ Early cut } & \multicolumn{2}{|c|}{ Late cut } & \multicolumn{2}{|c|}{ Early cut } & \multicolumn{2}{|c|}{ Late cut } \\
\hline & Mean & $\mathrm{SE}$ & Mean & SE & Mean & $\mathrm{SE}$ & Mean & $\mathrm{SE}$ \\
\hline 0 & $98 \cdot 4^{a}$ & $3 \cdot 9$ & $115 \cdot 4^{b}$ & 3.9 & $113 \cdot 7^{\mathrm{b}}$ & $1 \cdot 8$ & $102 \cdot 8^{\mathrm{ab}}$ & $4 \cdot 7$ \\
\hline 1 & $73 \cdot 3^{2}$ & $4 \cdot 6$ & $78.9^{a b}$ & $3 \cdot 5$ & $87 \cdot 9^{2 b}$ & $3 \cdot 0$ & $91 \cdot 8^{b}$ & 4.8 \\
\hline 2 & $79 \cdot 9^{\mathrm{a}}$ & $5 \cdot 5$ & $80 \cdot 2^{\mathrm{a}}$ & 4.9 & $75 \cdot 9^{\mathrm{a}}$ & $3 \cdot 2$ & $83 \cdot 3^{a}$ & $5 \cdot 2$ \\
\hline 3 & $76 \cdot 6^{\mathrm{a}}$ & $8 \cdot 9$ & $85 \cdot 3^{\mathrm{a}}$ & $13 \cdot 1$ & $75 \cdot 8^{\mathrm{a}}$ & $3 \cdot 8$ & $103 \cdot 5^{\mathrm{a}}$ & $7 \cdot 3$ \\
\hline
\end{tabular}

a, b Mean values with different superscript letters were significantly different $(P<0 \cdot 05)$

* For details of hays, see p. 494 and Table 1.

the late-cut hays, during both ingestion and rumination. A comparison of mastication time relative to $1 \mathrm{~kg}$ ingested DM revealed that while ryegrass at the early growth stage was more digestible than the lucerne, both had the same mastication time; for the late-cut hay, the time spent chewing ryegrass $(848 \mathrm{~min} / \mathrm{kg} \mathrm{DM})$ exceeded that of lucerne $(452 \mathrm{~min} / \mathrm{kg}$ DM), although the two hay types had almost identical digestibilities. This difference was due mainly to a prolongation of rumination time $/ \mathrm{kg}$ ingested $\mathrm{DM}$, which was perhaps a result of the way our animals were fed, i.e. a single meal daily over a period of $4 \mathrm{~h}$.

The ingestion rate, which is the reciprocal of unit eating time, varied for the four hay types. It was highest for early-cut ryegrass and lowest for late-cut ryegrass. In the $1 \mathrm{~h}$ following its presentation to the animals the amount of late-cut ryegrass ingested was the lowest, while the levels of intake of the other three hays were similar; over the next hour, the level of intake of late-cut lucerne was the highest and remained so during the whole meal (Table 3). From the percentage of intake consumed each hour, it appears that earlycut ryegrass and lucerne were eaten in a similar pattern, while the late-cut lucerne was eaten more slowly, but over a longer period, to give a higher intake; the late-cut ryegrass was eaten the most slowly.

The number of chews per min (Table 5) ranged from 73 to 115 and tended to decrease during the meal. The number of chews per g hay ingested (Fig. 1) varied from 3 to 22 ; they increased during the meal and were definitely higher for the late-cut hays, especially ryegrass $(P<0.05)$.

Particle size in the digestive tract. Bolus particle size measurements are given in Fig. 2. In the boluses obtained during ingestion, the percentage of particles collected on the $8 \mathrm{~mm}$ sieve was higher for the ryegrass than for the lucerne hays and was particularly high for early-cut ryegrass (Table 6). The percentage of particles collected on $1.6 \mathrm{~mm}$ sieves of boluses regurgitated at the moment of rumination was smaller $(P<0.05)$ than that of the boluses obtained at the moment of ingestion, and it was even smaller in those reswallowed after mastication.

The particle size analysis of rumen contents (Fig. 3) showed that the percentage of large particles collected on sieves of $1.6 \mathrm{~mm}$ or more, although lower than in the boluses collected during ingestion, was systematically higher $(P<0.05)$ in rumen contents obtained after the meal $(4 \mathrm{~h})$ than before the meal $(0 \mathrm{~h})$, following the arrival of the foodstuff boluses, while the opposite was observed for particles collected on sieves smaller than $1.6 \mathrm{~mm}$. The percentage of large particles collected on the $1.6 \mathrm{~mm}$ sieve $4 \mathrm{~h}$ after the meal was 


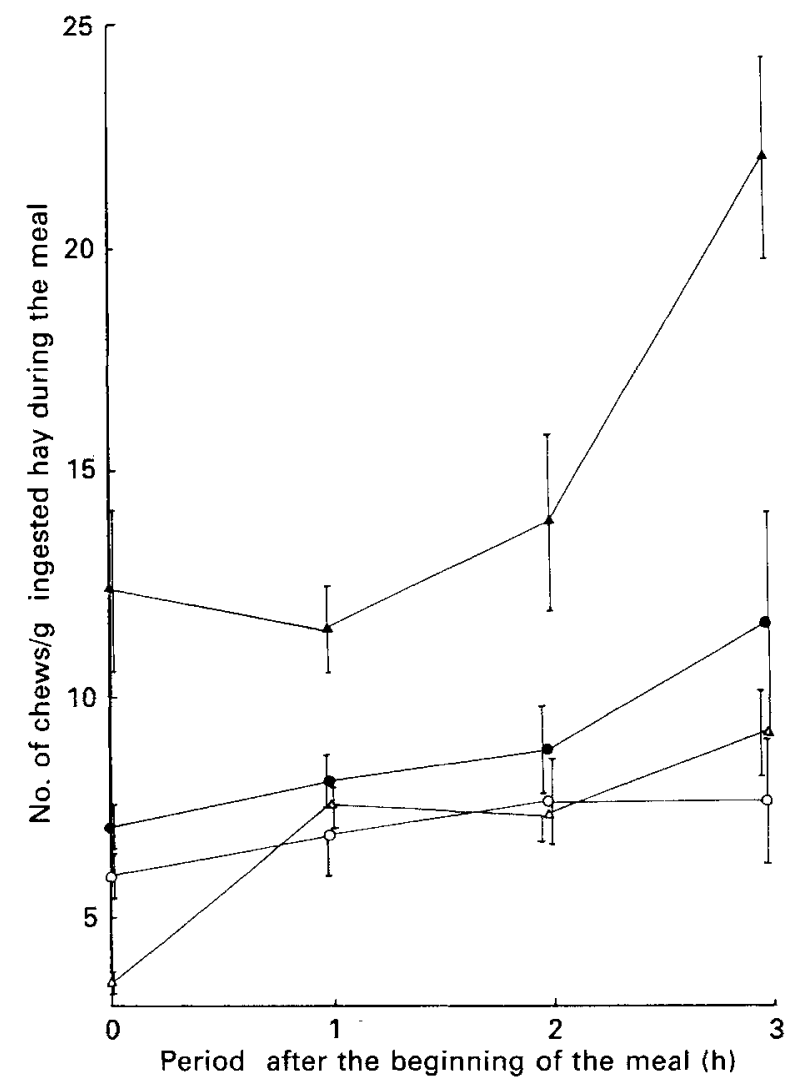

Fig. 1. Number of chews/g ingested hay during the meal measured on sheep fed on early-cut lucerne (Medicago sativa) $\left(\mathrm{O}^{-} \mathrm{O}\right)$, late-cut lucerne $(\mathbf{-}-\mathbf{O})$, early-cut ryegrass $($ Lolium italicum $)\left(\Delta^{-} \Delta\right)$ and late-cut ryegrass $(\mathbf{\Delta}-\mathbf{\Delta})$. Points are means with their standard errors represented by vertical bars. For details of hays, see p. 494 and Table 1.

Table 6. Amount of particles retained on the sieves $>8 \mathrm{~mm}$ or $>1.6 \mathrm{~mm}$ (\% of total dry matter) in the boluses and rumen contents of sheep fed on four types of hay*

(Mean values with their standard errors; no. of determinations in parentheses)

\begin{tabular}{|c|c|c|c|c|c|c|c|c|}
\hline & \multicolumn{4}{|c|}{ Lucerne (Medicago sativa) } & \multicolumn{4}{|c|}{ Italian ryegrass (Lolium italicum) } \\
\hline & \multicolumn{2}{|c|}{ Early cut } & \multicolumn{2}{|c|}{ Late cut } & \multicolumn{2}{|c|}{ Early cut } & \multicolumn{2}{|c|}{ Late cut } \\
\hline & Mean & SE & Mean & $\mathrm{SE}$ & Mean & $\mathrm{SE}$ & Mean & $\mathrm{SE}$ \\
\hline \multicolumn{9}{|l|}{ Boluses: Intake } \\
\hline$>8 \mathrm{~mm}$ & $16 \cdot 4^{a}(3)$ & $1 \cdot 1$ & $18 \cdot 7^{\mathrm{a}}(2)$ & $0 \cdot 5$ & $42 \cdot 9^{13}(2)$ & $2 \cdot 7$ & $28 \cdot 3^{\circ}(2)$ & $1 \cdot 6$ \\
\hline$>1.6 \mathrm{~mm}$ & $46 \cdot 8^{\mathrm{a}}(3)$ & $0 \cdot 9$ & $50 \cdot 1^{\mathrm{a}}(2)$ & 0.5 & $58 \cdot 4^{1}(2)$ & 0.5 & $67.9^{\circ}(2)$ & $1 \cdot 8$ \\
\hline $\begin{array}{l}\text { Regurgitation } \\
>1.6 \mathrm{~mm}\end{array}$ & $27 \cdot 9^{\mathrm{a}}(2)$ & $2 \cdot 1$ & $29 \cdot 6^{\mathrm{a}}(4)$ & 40 & $18 \cdot 7^{a}(3)$ & 1.4 & $23 \cdot 8^{\mathrm{n}}(4)$ & $9 \cdot 5$ \\
\hline Reswallowing & & & & & & & & \\
\hline $\begin{array}{c}>1.6 \mathrm{~mm} \\
\text { Rumen content }\end{array}$ & $13 \cdot 5^{\mathrm{a}}(2)$ & $1 \cdot 7$ & $16 \cdot 2^{\mathrm{a}}(4)$ & $1 \cdot 0$ & $26 \cdot 3^{b}(4)$ & $0 \cdot 9$ & $18 \cdot 8^{a}(6)$ & $1 \cdot 8$ \\
\hline $0 \mathrm{~h}>1.6 \mathrm{~mm}$ & $18 \cdot 5^{\mathrm{a}}(8)$ & $1 \cdot 1$ & $7 \cdot 2^{b}(6)$ & $0 \cdot 5$ & $6 \cdot 6^{11}(4)$ & $0-9$ & $9 \cdot 9^{\mathrm{b}}(8)$ & $1 \cdot 2$ \\
\hline $4 \mathrm{~h}>1.6 \mathrm{~mm}$ & $31 \cdot 1^{a}(8)$ & $0 \cdot 8$ & $35 \cdot 9^{a}(6)$ & $1 \cdot 3$ & $42 \cdot 8^{b}(6)$ & $4 \cdot 1$ & $34 \cdot 2^{\mathrm{a}}(6)$ & 1.5 \\
\hline
\end{tabular}

a,b,c Mean values with different superscript letters were significantly different $(P<0.05)$.

* For details of hays, see p. 494 and Table 1. 
Intake
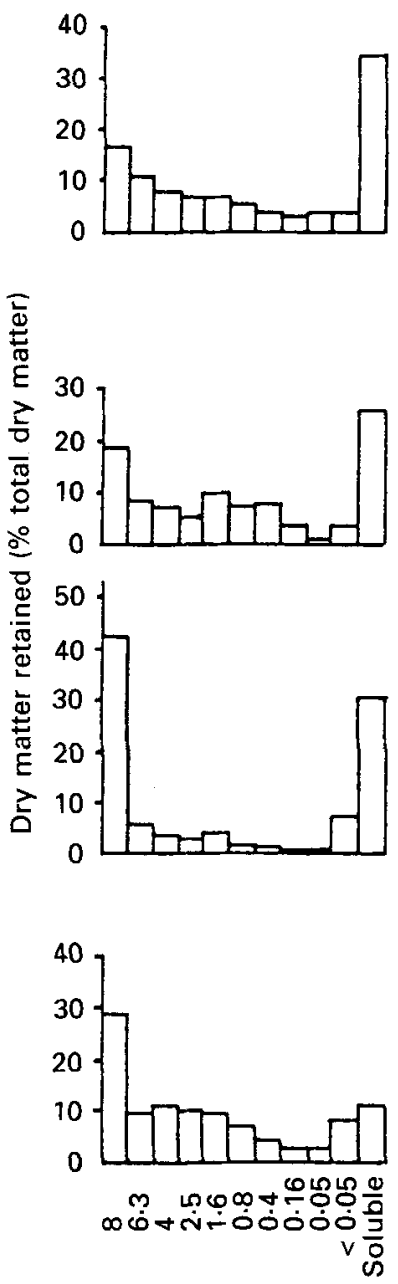

Regurgitation

Reswallowing

Early-cut lucerne
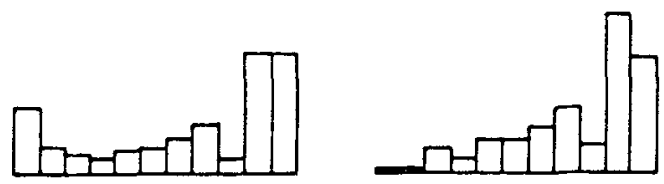

Late-cut lucerne
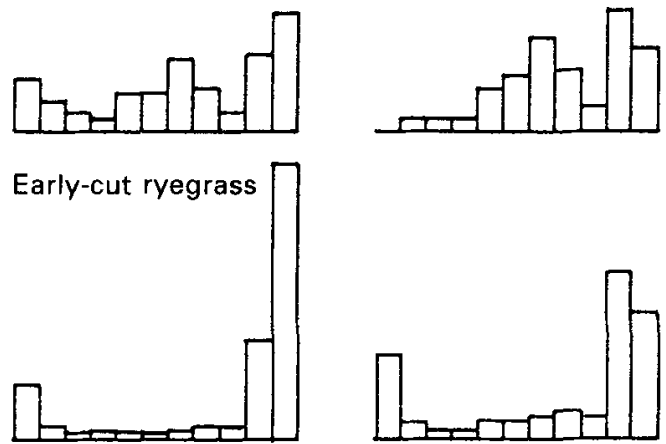

Late-cut ryegrass

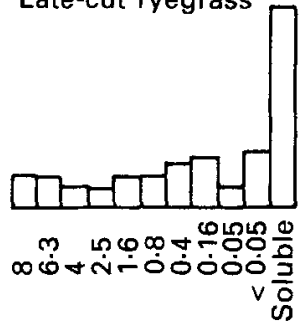

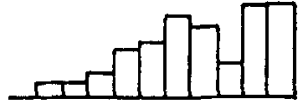

m $1000+\%$

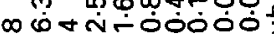

Sieve aperture $(\mathrm{mm})$

Fig. 2. Particle size analysis of the boluses collected during the meal and during rumination from oesophageally fistulated sheep fed on early-cut lucerne (Medicago sativa), late-cut lucerne, early-cut ryegrass (Lolium italicum) and late-cut ryegrass. For details of hays, see p. 494 and Table 1.

particularly high for early-cut ryegrass (Table 6). Before the meal it was highest for the early-cut lucerne.

Duodenal contents at $0 \mathrm{~h}$ and $4 \mathrm{~h}$ contained particles much smaller than those of rumen contents (Fig. 4); whatever the hay, they were almost all collected on sieves with a mesh size of less than $1.6 \mathrm{~mm}$. The faecal particles were also very small; on average, the faeces contained much less soluble material than duodenal contents.

Rumen emptying. Amounts of fresh matter, DM and particles (the amount of watersoluble contents was subtracted from DM to give particles) in the rumen generally varied with the forages (Table 4). The quantities of fresh matter before the meal differed for the four hays, but the differences were not significant; after the meal, they were much larger but varied little from one hay to another. Amounts of DM and particles in the rumen 
$\mathrm{Oh}$

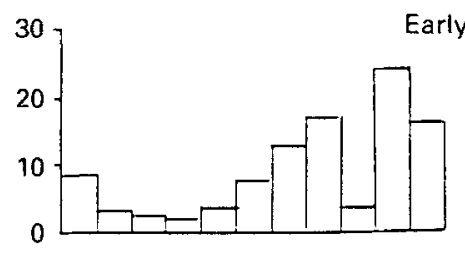

$4 \mathrm{~h}$

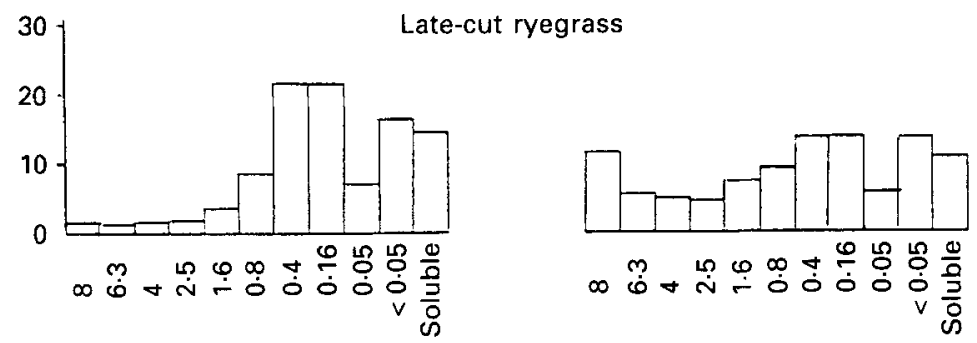

Sieve aperture $(\mathrm{mm})$

Fig. 3. Particle size analysis of the rumen contents collected before $(0 \mathrm{~h})$ and after $(4 \mathrm{~h})$ the meal from fistulated sheep fed on early-cut lucerne (Medicago sativa), late-cut lucerne, early-cut ryegrass (Lolium italicum) and latecut ryegrass. For details of hays, see p. 494 and Table $t$.

tended to be larger with late-cut compared with early-cut hays both before and after the meal. They were systematically higher at $4 \mathrm{~h}$ than at $0 \mathrm{~h}$.

The amount of DM leaving the rumen over the $4 \mathrm{~h}$ was calculated as follows : the amount of DM present in the rumen at $4 \mathrm{~h}$ was subtracted from the sum of DM present at $0 \mathrm{~h}$ and that ingested between 0 and $4 \mathrm{~h}$. However, the level of hay intake of the fistulated sheep varied from day-to-day. Therefore, to allow for this variability, the amount of DM present in the rumen at $0 \mathrm{~h}$ was adjusted. Since the relation between the amount of DM in the rumen at $0 \mathrm{~h}$ and that ingested the previous day was very close, the ratio between these two values for each sheep and each hay was determined and then multiplied by the amount of 
$\mathrm{Oh}$
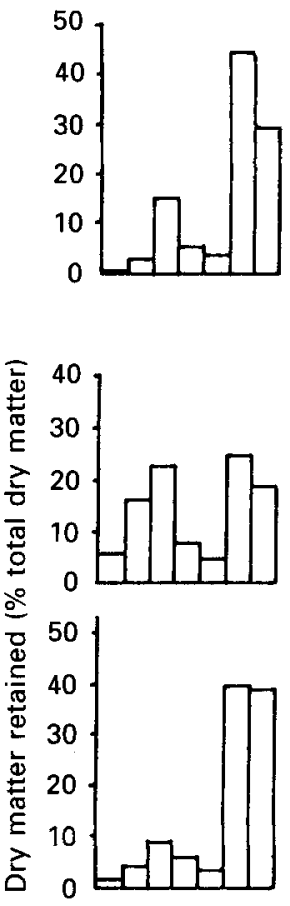

$4 \mathrm{~h}$

Early-cut lucerne
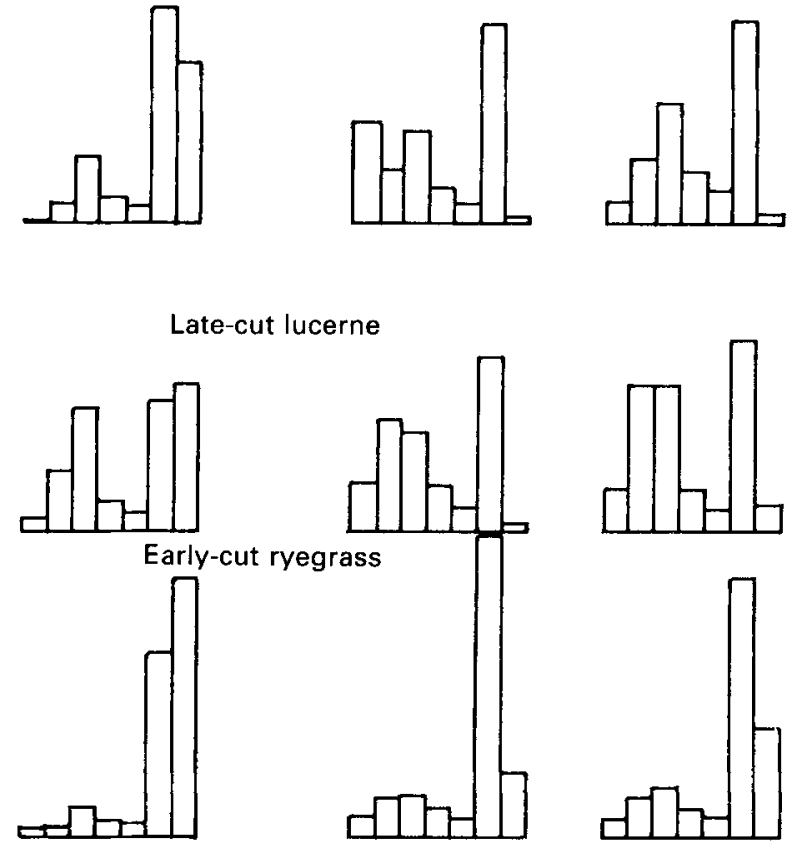

Late-cut ryegrass

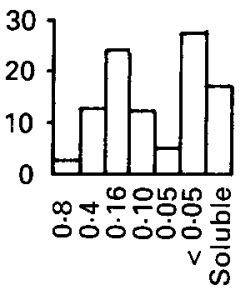

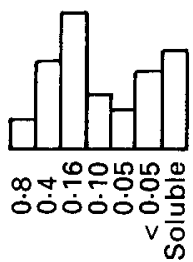

(b) Duodenum

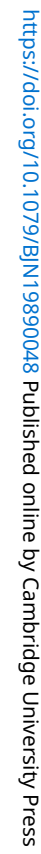

Sieve aperture $(\mathrm{mm})$

Fig. 4. Particle size analysis of duodenal contents collected before $(0 \mathrm{~h})$ and after $(4 \mathrm{~h})$ the meal on duodenally fistulated sheep, and of faeces collected from $(a)$ rumen-fistulated sheep and $(b)$ duodenally fistulated sheep. All the sheep were fed on early-cut lucerne (Medicago sativa), late-cut lucerne, early-cut ryegrass (Lolium italicum) and late-cut ryegrass. For details of hays, see p. 494 and Table 1.

DM ingested before the emptying at $4 \mathrm{~h}$, in order to obtain the rumen content at $0 \mathrm{~h}$ on the same day. The amount ingested indicated in Table 4 is that of the day when rumen emptying took place $4 \mathrm{~h}$ after the meal.

The rate at which DM left between 0 and $4 \mathrm{~h}$ was particularly high with late-cut lucerne, a little less with early-cut ryegrass and much lower with the other two hays (Table 4). It was lower during the next $20 \mathrm{~h}$ and differed little between hays, ranging from 36 to $48 \mathrm{~g} / \mathrm{h}$; with early-cut lucerne, late-cut lucerne and early-cut ryegrass it became two, four and three times less rapid respectively, but it varied little with late-cut ryegrass. The rate of disappearance of particles from the rumen also differed for the four hay types during the $4 \mathrm{~h}$ following the 
$8 \mathrm{~h}$

$24 \mathrm{~h} \quad 48 \mathrm{~h}$

$72 \mathrm{~h}$

Early-cut lucerne
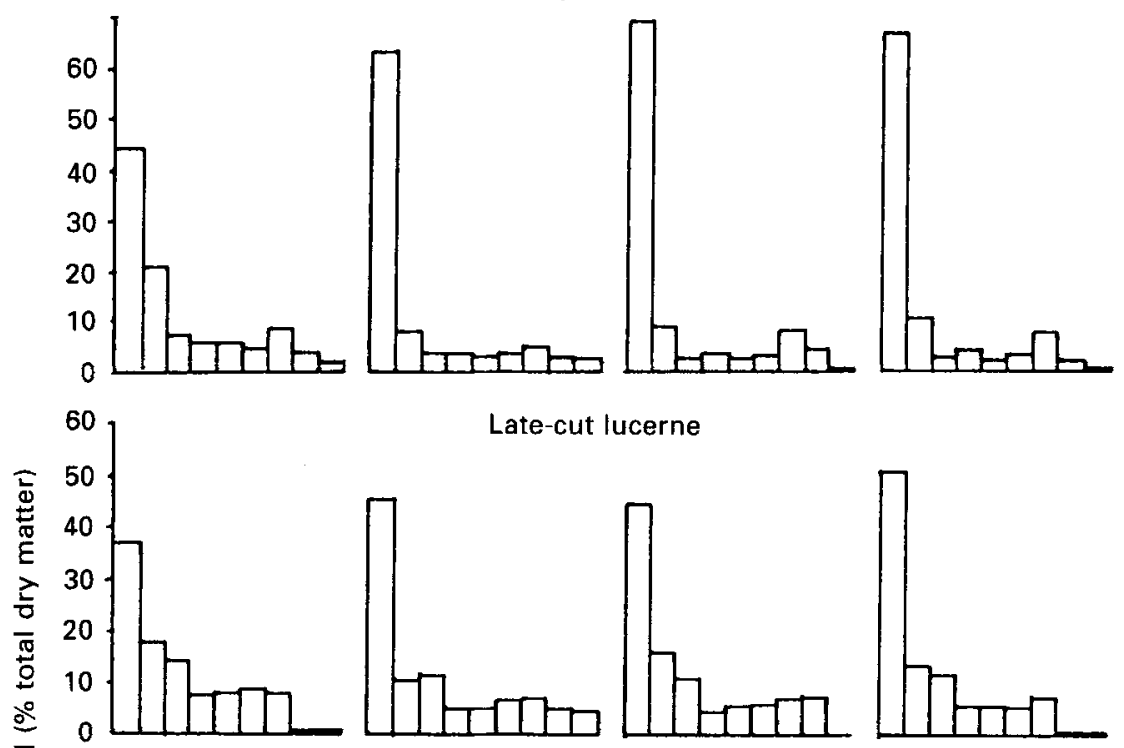

Late-cut lucerne
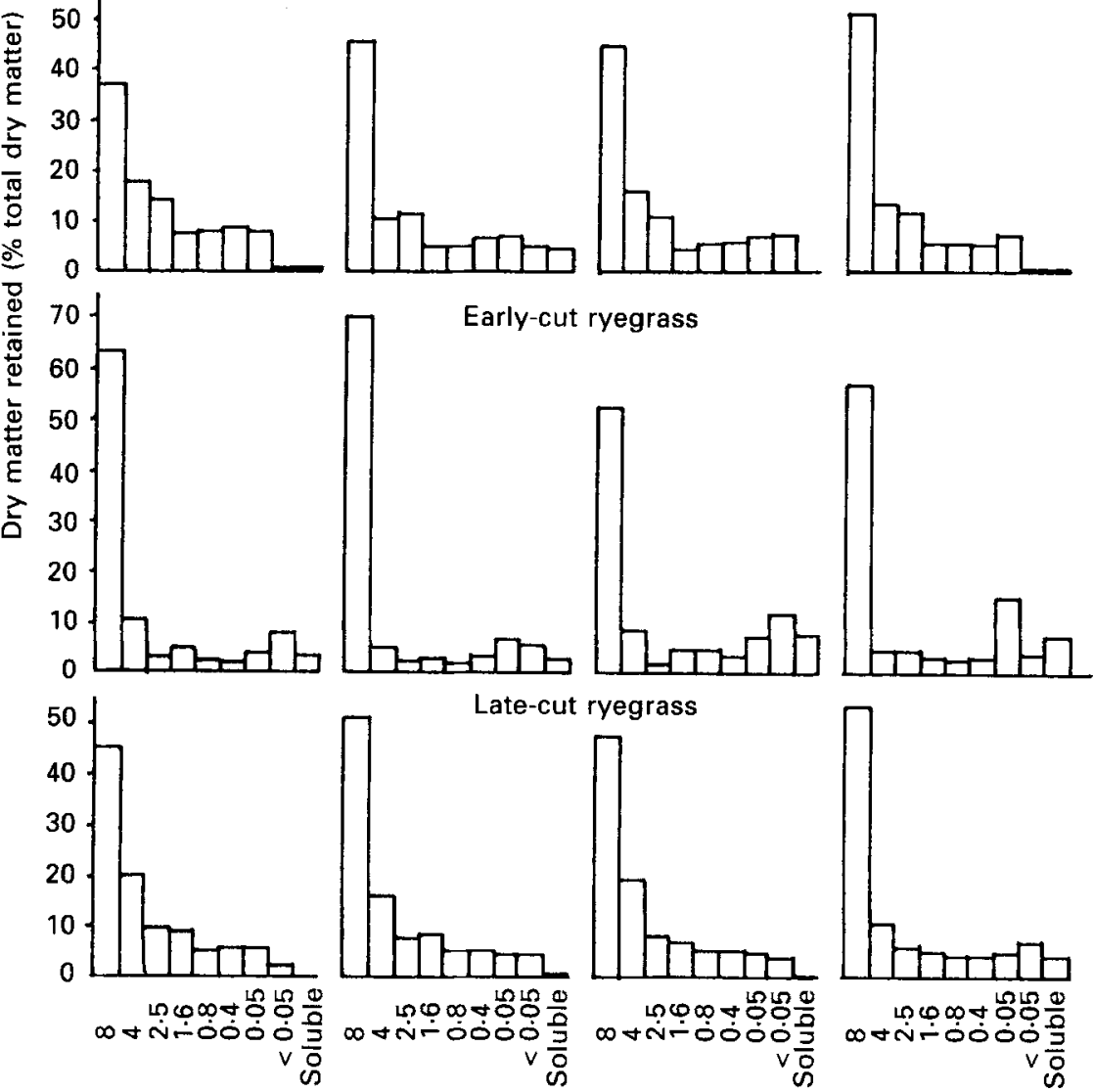

Sieve aperture $(\mathrm{mm})$

Fig. 5. Particle size analysis of contents of nylon bags, put in the rumen for $8,24,48$ and $72 \mathrm{~h}$, containing the boluses collected during the meal from sheep fed on early-cut lucerne (Medicago sativa), late-cut lucerne, earlycut ryegrass (Lolium italicum) and late-cut ryegrass. For details of hays, see p. 494 and Table 1.

meal. With late-cut lucerne, it was very high (higher than that of the other hays) and was lowest with late-cut ryegrass. During the rest of the day, the rates of disappearance of the particles ranged from 28 to $40 \mathrm{~g} / \mathrm{h}$; the higher the rates between 0 and $4 \mathrm{~h}$ the lower they were over the rest of the day. 
Particle size analysis of boluses in nylon bags. For all residence times the proportion of particles collected on the $8 \mathrm{~mm}$ sieve was very high in the boluses held in bags (Fig. 5), varying between 40 and $70 \%$ of total $\mathrm{DM}$. This percentage tended to increase with residence time in the rumen while simultaneously some of the DM disappeared from the bag, no doubt owing to the loss of small particles by microbial digestion. For early-cut ryegrass, the proportion of particles collected on the $8 \mathrm{~mm}$ sieve increased between 08.00 and 24.00 hours, whereas afterwards it decreased and the proportion of small particles increased.

\section{DISCUSSION}

The intake of early-cut lucerne by fistulated animals given a single meal daily was lower than that of late-cut lucerne hay. The ingestion time was also shorter, $2 \mathrm{~h} 24$ min compared with $4 \mathrm{~h}$. With the very easily fermented early-cut lucerne it could be that satiety was due to an accumulation of gas or to other digestive or even metabolic effects. An intact animal with hay continuously available would be able to compensate for the slowness of the ingestion by increasing its duration; fistulated animals fed for only $4 \mathrm{~h}$ could not do this. We chose this method of feed distribution because it made it easier to measure the rumenemptying rate. However, the results we obtained explain only the mechanisms controlling the ingestion of lucerne and ryegrass hays given once daily over $4 \mathrm{~h}$.

Measurements of feeding activity in the sheep receiving the four types of hay showed that the number of chews per $\mathrm{g}$ ingested hay varied much more than the number of chews per min and was particularly high for late-cut ryegrass compared with the other hays. The percentage of particles collected on the $1.6 \mathrm{~mm}$ sieve in the boluses collected during the meal (Table 3) was larger with ryegrass than with lucerne, which is in keeping with the results of Lee \& Pearce (1984). Thus late-cut ryegrass, which was masticated more during ingestion than late-cut lucerne, gave larger particles. This indicates that it was more resistant to mastication, a fact already noted with perennial ryegrass (Lolium perenne) by Evans (1967) and Ulyatt et al. (1986). The most surprising observation was that the percentage of particles collected on the $8 \mathrm{~mm}$ sieve of early-cut ryegrass was even larger than that of the other three hays. Pond et al. (1985) obtained similar results with a grass at three different stages of harvesting. It may be suggested, in agreement with G. Moseley (personal communication), that the more lignified, late-cut ryegrass was more easily broken by the teeth than the early-cut, less lignified and more supple ryegrass, and that it was more easily ground into small fragments.

The collection of boluses via the oesophageal fistula either at the moment of ingestion or rumination presents some problems. When the cannula is withdrawn during ingestion and the boluses fall outside the animal, a fraction of saliva, enriched with soluble hay constituents and containing suspended small particles, reaches the rumen directly (C. S. W. Reid, personal communication). As a consequence, particle size in these boluses might have been overestimated. The collection of boluses at the moment of rumination requires the presence of an operator beside the animal to separate the regurgitated boluses from the reswallowed ones. Even when the animal was accustomed to the operator any environmental disturbance stopped the rumination for a long period. Thus, it was not possible to collect rumination boluses systematically from all the oesophageal-fistulated animals. In addition, when the boluses were regurgitated and masticated during rumination, a fraction (mainly liquid) was immediately reswallowed. This fraction, the tail bolus described by Kennedy (1985) may, therefore, have escaped sampling, so that the sizes of the particles in the boluses were perhaps overestimated.

The major role played by rumination in the size reduction of large particles in the rumen contents (Kennedy, 1985) was confirmed by the present study. The quantity of particles 
collected on sieves with a mesh size equal or superior to $1.6 \mathrm{~mm}$, expressed as a percentage of the total amount of particles, was reduced by about $50 \%$ by rumination in the casc of lucerne hays. These results confirm that ryegrass was more resistant to mastication than lucerne. Particle size analysis of the boluses held in the bags, after residence times in the rumen ranging from 8 to $72 \mathrm{~h}$ (Fig. 5), showed that the particles of a very digestible and little-lignified forage such as the early-cut ryegrass hay could be partly broken down by the micro-organisms. However, with more lignified forages mastication played a major role by offering to the bacteria a much larger surface on the cell walls to attack (Van Soest, 1982). The histological structure of forages markedly affects their fate in the digestive tract (Akin, 1979; Moseley \& Jones, 1984; Pond et al. 1984; Grenet \& Demarquilly, 1987) by factors which have not yet been fully elucidated.

It is noteworthy that the rate of disappearance of late-cut ryegrass hay from the rumen was fivefold lower than that of late-cut lucerne with the same digestibility. The DM disappearance from the rumen results both from microbial digestion and passage out of the rumen. The digestion of the late-cut ryegrass hay was threefold lower than that of the latecut lucerne hay. Moreover, since late-cut ryegrass hay was more resistant to mastication than late-cut lucerne hay, it was broken down more slowly into small particles, and its microbial digestion and escape from the rumen took longer. Before the meal, the rumen contained a large proportion of particles retained on sieves of less than $1.6 \mathrm{~mm}$. These particles were small enough to escape the rumen, but they were probably retained in the raft of large particles so that they were immobilized (Ulyatt et al. 1986). During the meal the number of reticulum contractions increased (Colvin et al. 1978; Cirio Maisonnave et al. 1981; Waghorn \& Reid, 1983) leading to an acceleration in the escape of small particles. The present results and those of Moseley \& Jones (1984), Aitchison et al. (1986), Grenet (1987) and Baumont et al. (1988), show that the rate of disappearance of DM from the rumen, both by digestion and by passage, was higher during the meal than during the following period. The hay with the longest ingestion time led to the greatest number of reticulum contractions and the largest loss of particles during the meal.

The results show that in animals fed once daily over $4 \mathrm{~h}$ lucerne hay disappeared more quickly from the rumen than ryegrass hay of the same digestibility. The digestion rate of lucerne hay was higher than that of ryegrass hay and lucerne hay was also more easily chewed into small particles. These differences might explain why, under the present experimental conditions and for the same digestibility, lucerne hay was ingested in larger quantities than ryegrass hay, and they suggest that in animals fed ad lib. the same mechanisms are involved.

The author wishes to thank J. Robelin for assistance with statistical analyses, Dr G. Moseley of the Welsh Plant Breeding Station (UK) for helpful advice in the interpretation of results, L. L'Hotelier, Madeleine Dudilieu, Marie Jailler and Jacqueline Jamot for technical assistance, Kirsten Rérat for the translation into English and Dr J. Mason of Trinity College (Irish Republic) for helpful criticisms in the preparation of the manuscript.

\section{REFERENCES}

Aitchison, E. M. (1985). A study of the removal of fibre from the rumen and voluntary intake of sheep eating hay diets. PhD Thesis, University of Reading.

Aitchison, E. M., Gill, M., Dhanoa, M. S. \& Osbourn, D. F. (1986). The effect of digestibility and forage species on the removal of digesta from the rumen and the voluntary intake of hay by sheep. British Journal of Nutrition 56, 463-476.

Akin, D. E. (1979). Microscopic evaluation of forage digestion by rumen microorganisms. A review. Journal of Animal Science 48, 701 710.

Baumont, R., Dulphy, J. P. \& Andrieu, J. P. (1988). Comportement alimentaire et état de réplétion du reticulo- 
rumen chez le mouton nourri à volonté de foin de prairie ou de luzerne, avec accès continu ou limité: incidences sur le contrôle physique de l'ingestion. Reproduction, Nutrition, Développement 28, 573-588.

Cirio Maisonnave, A., Boivin, R. \& Bost, J. (1981). Stimulation prandiale de la motricité réticulaire chez le mouton: phase céphalique et réflexe oral. Annales de Recherches Vétérinaires 12, 291-302.

Colvin, H. W. Jr, Digesti, R. D. \& Louvier, J. A. (1978). Effect of succulent and nonsucculent diets on rumen motility and pressure before, during and after eating. Journal of Dairy Science 61, 1414-1421.

Demarquilly, C. \& Chenost, M. (1969). Etude de la digestion des fourrages dans le rumen par la méthode des sachets de nylon. Liaison avec la valeur alimentaire. Annales de Zootechnie 18, 419-436.

Demarquilly, C. \& Weiss, P. (1970). Tableaux de la valeur alimentaire des Fourrages Verts. Etude S.E.I. no. 42. Versailles: INRA.

Dulphy, J. P. (1971). Influence du poids vif 'et du niveau d'ingestion sur le comportement alimentaire et mérycique du mouton. Annales de Zootechnie 20, 477-486.

Evans, P. S. (1967). Leaf strength studies of pasture grasses. II. Strength, cellulose content and sclerenchyma tissue proportions of eight grasses grown as single plants. Journal of Agricultural Science, Cambridge 69, 175-181.

Goering, H. K. \& Van Soest, P. J. (1970). Forage fiber analyses. Agricultural Handbook no. 379. Washington DC: US Department of Agriculture.

Grenet, E. (1970). Taille et structure des particules végétales au niveau du feuillet et des fèces chez les bovins. Annales de Biologie Animale, de Biochimie et de Biophysique 10, 643-657.

Grenet, E. (1984). Wet sieving technique for estimating particle size in herbivore digesta. In Techniques in Particle Size Analysis of Feed and Digesta in Ruminants, p. 167 [P. M. Kennedy, editor]. Edmonton: Canadian Society of Animal Science.

Grenet, E. (1987). Etude comparée de la vitesse de vidange du rumen chez le mouton alimenté avec des foins de graminées et de légumineuses. Reproduction, Nutrition, Développement 27, 229-230.

Grenet, E. \& Demarquilly, C. (1987). Rappels sur la digestion des fourrages dans le rumen (parois) et ses conséquences. In Les Fourrages Secs: Récolte, Traitement, Utilisation, pp. 141-162 [C. Demarquilly, editor]. Paris: INRA.

Kennedy, P. M. (1985). Effect of rumination on reduction of particle size in rumen digesta by cattle. Australian Journal of Agricultural Research 36, 819828.

Lee, J. A. \& Pearce, G. R. (1984). The effectiveness of chewing during eating on particle size reduction of roughages by cattle. Australian Journal of Agricultural Research 35, 609-618.

Moseley, G. \& Jones, J. R. (1984). The physical digestion of perennial ryegrass (Lolium perenne) and white clover (Trifolium repens) in the foregut of sheep. British Journal of Nutrition 52, 381-390.

Pond, K. R., Burns, J. C. \& Tate, L. P. (1985). Particle size distribution from masticated switch grass of different maturities. Journal of Animal Science 61, Suppl, 350.

Pond, K. R., Ellis, W. C. \& Akin, D. E. (1984). Ingestion, mastication and fragmentation of forages. Journal of Animal Science 58, 1567-1574.

Poppi, D. P., Norton, B. W., Minson, D. J. \& Hendricksen, R. E. (1980). The validity of the critical size theory for particles leaving the rumen. Journal of Agricultural Science, Cambridge 94, 275-280.

Ruckebusch, Y. (1963). Recherches sur la régulation centrale du comportement alimentaire chez les ruminants. Thèse de Doctorat de Sciences, Université de Lyon.

SAS (1985). Stat Guide for Personal Computer. Cary, N. C.: Statistical Analysis System Institute Inc.

Ulyatt, M. J., Dellow, D. W., John, A., Reid, C. S. W. \& Waghorn, G. C. (1986). The contribution of chewing, during eating and rumination, to the clearance of digesta from the rumino-reticulum. In Control of Digestion and Metabolism in Ruminants, pp. 498-515 [L. P. Milligan, W. L. Grovum and A. Dobson, editors]. Englewood Cliffs, NJ: Prentice Hall.

Van Soest, P. J. (1982). Nutritional Ecology of the Ruminant. Corvallis, Oregon: O \& B Books.

Waghorn, G. C. \& Reid, C. S. W. (1983). Rumen motility in sheep and cattle fed different diets. New Zealand Journal of Agricultural Research 26, 289-295. 